\title{
Synthesis of an Advanced Intermediate En Route to the Mitomycin Natural Products
}

\author{
Amie L. Williams $\S$, Jayasree M. Srinivasan§, and Jeffrey N. Johnston ${ }^{\star}$ \\ Department of Chemistry, Vanderbilt University, Nashville, TN 37235-1822
}

\section{Abstract}

An advanced intermediate in our planned synthesis of mitomycin $\mathrm{C}$ has been acquired in nine steps from tert-butyl glyoxylate. The aziridinyl pyrrolidine and quinone subunits are coupled regioselectively to arrive at an enamine that is prepared for $\mathrm{C} 10$ homologation.

The mitomycin natural products have attracted the attention of medicinal and synthetic chemists for nearly a half century. ${ }^{1,2}$ This interest results from several factors, including the continued clinical use of mitomycin C (1) for treatment of various forms of cancer. The unique pyrroloquinone backbone presents a high degree and density of oxidation, and this functional group array is the source of mitomycin C's unique ability to crosslink DNA. ${ }^{3}$ Consequently, a substantial challenge for chemical synthesis is presented. Indeed, there have been many reports detailing synthetic efforts toward this class of natural products, and although interest has not waned with the passing of time, only two total syntheses of the title compound ${ }^{4}$ and two syntheses of another member of the class, mitomycin $\mathrm{K}(3)^{5}$, have been logged.

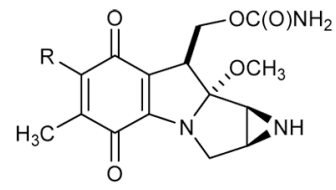<smiles>C=C1C2=C(C(=O)C(C)=C(OC)C2=O)N2CC3NC1(C)C32C</smiles>

$\begin{array}{ll}\text { 1, } \mathrm{R}=\mathrm{NH}_{2} & \text { mitomycin } \mathrm{C} \longleftarrow \mathrm{NH}_{3} \\ \text { 2, } \mathrm{R}=\mathrm{OMe} & \text { mitomycin } \mathrm{A} \\ \mathrm{MeOH}\end{array}$

mitomycin K (3)

A successful synthesis, particularly one amenable to derivative formation, might further improve the therapeutic profile for this natural product class, ${ }^{6}$ and rejuvenate efforts to use contemporary biochemical techniques to similarly improve efficacy.

To achieve a high degree of convergency, our retrosynthesis disconnects the aziridinopyrrolidine and quinone across the central dihydropyrrole ring. On the basis of our previous studies of regioselective enamine additions to methoxy quinones, ${ }^{7}$ we expected the coupling of enamine $\mathbf{6}$ to quinone $\mathbf{7}$ to be regioselective for methoxy substitution at the bromomethoxy olefin. ${ }^{8}$ Construction of enamine 6 could arise from a cyclization of an amino alkyne via formal alkyne hydroamination. Convergency could again be served if an aziridine ring-forming reaction could be used that would also form the aziridine carbon-carbon bond. Hence, we began our studies by investigating the traditional methods for aziridine construction by carbon-carbon bond formation. ${ }^{9}$

jeffrey.n.johnston@ vanderbilt.edu.

sIndiana University, Bloomington, IN 47405. 
Scheme 1 lists several general lines of investigation toward this end. Based on the work of $\mathrm{O}^{\prime}$ Donnell ${ }^{10}$ and Miller, ${ }^{11}$ we anticipated that glycinyl Schiff base $\mathbf{8}$ might engage propargyl aldehyde 7 in an aldol reaction. The resulting $\beta$-hydroxy ester could be converted to the corresponding mesylate. In order to avoid competitive cyclization to the corresponding oxazoline, ${ }^{12}$ in situ trapping with mesyl chloride was necessary. Reductive amination then provided the desired aziridine in good overall yield. Unfortunately, the initial addition was minimally diastereoselective and favored the undesired trans-isomer.

The Darzens reaction ${ }^{13}$ using an azomethine electrophile provided a more direct route to the aziridine since it avoided the necessity to activate the hydroxy imine intermediate in eq 1 and reduce the imine functionality. ${ }^{14}$ The reaction of propargyl imine $\mathbf{1 0}$ under these conditions provided only trace amounts of aziridine, much less the desired cis-9. By activating the imine electrophile without resorting to a more robust protecting group at nitrogen, we examined the diphenylmethyl amine Schiff base of ethyl glyoxylate (11). Combination of the reactants at low temperature, followed by slow warming to room temperature, resulted in modest yields of the desired aziridine. Of greater significance is the high cis-diastereoselection observed in this transformation, a prerequisite for eventual formation of the aziridinopyrrolidine. Substitution of chloroacetonitrile for tert-butyl chloroacetate was also effective and cis-selective, but provided a greater amount of competing nitrile homocoupling.

Conversion of the cis-aziridinosuccinate $\mathbf{1 2}$ to enamine precursor $\mathbf{1 6}$ (Scheme 2) began with selective saponification of the ethyl ester using aqueous sodium hydroxide in ethanol (97\%). Straightforward coupling of the carboxylic acid with commercial $(S)$ - $\alpha$-methyl benzylamine (98\% ee) was achieved in $74 \%$ yield using DCC/HOBT to furnish diastereomeric cis-aziridines $\mathbf{1 4 a} / \mathbf{b}$. Selective reduction of tert-butyl ester 14 provided the corresponding aldehydes in good yield as judged by spectroscopic analysis of the crude reaction mixture. Careful chromatographic separation at this stage provided the diastereomeric cis-aziridines in pure form, however at the expense of chemical yield due to their instability. Subsequent alkynylation of the less polar aldehyde was effected using the Gilbert-Seyferth phosphonate reagent. ${ }^{15}$ In this manner, the terminal alkyne was produced in $85 \%$ yield from 14a. Red-Al reduction of the amide was similarly effective, and alkynyl amine 16a was obtained in $79 \%$ yield. Upon standing for one week, this amine crystallized and single crystals could be obtained by slow evaporation from dichloromethane. X-ray crystallographic analysis enabled assignment of the stereochemistry depicted in Scheme 2.

An aminomercuration/coupling sequence was next evaluated with quinone 5 (Scheme 3). Enamine $\mathbf{6 b}$ was generated in situ by treatment of alkynylamine $16 \mathbf{b}^{16}$ with $\mathrm{Hg}(\mathrm{II}),{ }^{17}$ and this solution was added to quinone $\mathbf{5}$. The resulting deep blue solution was concentrated at $0{ }^{\circ} \mathrm{C}$. Analysis of this crude reaction mixture by ${ }^{1} \mathrm{H}$ NMR suggested selective and efficient production of a coupled product (see SI for details). However, successful purification of the putative enamine required cold column chromatography (ice water cooling). Using the bright color of the conjugated system as an indicator during this process, a product was isolated and kept at low temperature during NMR analysis. Notwithstanding, the material decomposed slowly with an approximate half-life of 1.5 days at $-15^{\circ} \mathrm{C}$. The reactivity of this intermediate, manifested as instability during purification, is a feature we anticipated and desired as part of our synthesis strategy; notwithstanding, we sought to fully characterize it by spectroscopic means.

Immediate recognition of several features suggested its identity to be $\mathbf{4 b}$. The aminobenzyl methine proton resonances are readily differentiated by chemical shift. The methine of the enamine is consistently deshielded to $4-5 \mathrm{ppm}$. The corresponding aziridine DPM-methine is further upfield at 3-4 ppm. HMBC, HMQC, and COSY experiments allowed assignment of all proton and carbon resonances. The coupling regiochemistry was identified by ${ }^{3} J_{\mathrm{CH}}$ between 
the enamine proton resonance (H9) and the quinone carbonyl carbon (C8) nearest the methoxy substituent. The latter was assigned indirectly by identification of the companion quinone carbonyl (C5) for which a ${ }^{3} J_{\mathrm{CH}}$ crosspeak could be observed from the quinone ring methyl subsituent. Consistent with our earlier observation, the methoxy group is preferentially substituted despite the electronic counter-influence of the distal methoxy. This behavior is consistent with rate-limiting addition in this nucleophilic vinylogous acyl substitution. The geometry of the newly formed enamine olefin was assigned by analogy to similar reactions we have investigated, all of which provide the $E$-olefin stereoisomer. ${ }^{7}$

In summary, we have arrived at an advanced intermediate (4) in our approach to the synthesis of the antitumor agent mitomycin $\mathrm{C}$. This is accomplished in only nine steps from ethyl glyoxylate. The next significant step is homologation to install the $\mathrm{C} 10$ hydroxymethyl; the enamine character of $\mathbf{4}$, as well as the steric influence of the aziridine are perfectly suited to this task. Details on this front will be the subject of future reports.

\section{Supplementary Material}

Refer to Web version on PubMed Central for supplementary material.

\section{Acknowledgment}

We are grateful to the National Institutes of Health (GM-63577) for support of this work. A.L.W. (IU) is the recipient of a Procter \& Gamble graduate fellowship. J.N.J. (VU) is grateful for young investigator awards from Eli Lilly, Amgen, Astellas, and Boehringer-Ingelheim. We acknowledge the assistance provided by Dr. Doug Brown for the low temperature NMR experiments, and by Maren Pink for the X-ray structural determination of $\mathbf{1 6 a}$.

\section{References}

1. Isolation and initial structure determination. (a) Webb JS, Cosulich DB, Mowat JH, Patrick JB, Broschard RW, Meyer WE, Williams RP, Wolf CF, Fulmor W, Pidacks C, Lancaster JE. J. Am. Chem. Soc 1962;84:3185. (b) Webb JS, Cosulich DB, Mowat JH, Patrick JB, Broschard RW, Meyer WE, Williams RP, Wolf CF, Fulmor W, Pidacks C, Lancaster JE. J. Am. Chem. Soc 1962;84:3187. (c) Tulinsky A. J. Am. Chem. Soc 1962;84:3188.

2. Selected recent leading references: (a) Coleman RS, Felpin F-X, Chen W. J. Org. Chem 2004;69:7309. [PubMed: 15471485] (b) Vedejs E, Little J. J. Am. Chem. Soc 2002;124:748. [PubMed: 11817939] (c) Papaioannou N, Evans CA, Blank JT, Miller SJ. Org. Lett 2001;3:2879. [PubMed: 11529780] (d) Ziegler FE, Berlin MY, Lee K, Looker AR. Org. Lett 2000;2:3619. [PubMed: 11073659] (e) Ban Y, Nakajima S, Yoshida K, Mori M, Shibasaki M. Heterocycles 1994;39:657. (f) Lee J, Ha JD, Cha JK. J. Am. Chem. Soc 1997;119:8127. (g) Luly JR, Rapoport H. J. Org. Chem 1984;49:1671.

3. (a) Tomasz M. Chem. Biol 1995;2:575. [PubMed: 9383461]Sheldon PJ, Johnson DA, August PR, Liu H-W, Sherman DH. Dev. Ind. Microbiol 1997;34:123. (b) Gargiulo D, Musser SS, Yang L, Fukuyama T, Tomasz M. J. Am. Chem. Soc 1995;117:9388.Verweij, J.; Sparreboom, A.; Nooter, K. Ch. 3. In: Pinedo, HM.; Longo, DL.; Chabner, BA., editors. Cancer Chemotherapy and Biological Response Modifiers Annual. New York: Elsevier; 1999. (d) Crown JP. Anti-Cancer Drugs 1999;10:S19. [PubMed: 10630364]

4. rac-1,2: (a) Kishi Y, Fukuyama T. J. Nat. Prod 1979;42:549. (b) Fukuyama T, Yang L. J. Am. Chem. Soc 1989;111:8303.

5. rac-3: (a) Benbow JW, Schulte GK, Danishefsky SJ. Angew. Chem. Int. Ed. Engl 1992;31:915. See also (b) Danishefsky SJ, Schkeryantz JM. Synlett 1995:475. (c) Wang Z, Jiminez LS. Tetrahedron Lett 1996;37:6049.

6. Kasai M, Kono M. Synlett 1992:778.

7. Cox AL, Johnston JN. Org. Lett 2001;3:3695. [PubMed: 11700115]

8. (a) Theodorakis EA, Ling T, Rueden EJ, Poupon E, Kim SH. Strat. Tactics Org. Synth 2004;5:111. (b) Ling T, Poupon E, Rueden RJ, Kim SH, Theodorakis EA. J. Am. Chem. Soc 2002;124:12261. [PubMed: 12371868] (c) Ling T, Poupon E, Rueden EJ, Theodorakis EA. Org. Lett 2002;4:819. 
[PubMed: 11869136] (d) Stagliano KW, Lu Z, Emadi A, Harwood JS, Harwood CA. J. Org. Chem 2004;69:5128. [PubMed: 15255750]

9. (a) Sweeney JB. Chem. Soc. Rev 2002;31:247. [PubMed: 12357722] (b) Graham MA, Thornton-Pett M, Rayner CM, Wadsworth AH. Chem. Commun 2001:966.

10. O’Donnell, MJ. Ch. 10. In: Ojima, I., editor. Catalytic Asymmetric Synthesis. 2nd ed. New York: Wiley-VCH; 2000.

11. Gasparski CM, Miller MJ. Tetrahedron 1991;47:5367.

12. (a) Van Ornum SG, Bruendl MM, Cao H, Reddy M, Grubisha DS, Bennett DW, Cook JM. J. Org. Chem 2000;65:1957. [PubMed: 10774014] (b) MacMillan JB, Molinski TF. Org. Lett 2002;4:1883. [PubMed: 12027638]

13. Darzens G. Compt. Rend 1904;139:1214.

14. (a) Wartski L. J. Chem. Soc. Chem. Commun 1977:602. (b) Cainelli G, Panunzio M. Tetrahedron Lett 1991;32:121. (c) Vedejs E, Piotrowski DW, Tucci FC. J. Org. Chem 2000;65:5498. [PubMed: 10970287]

15. (a) Seyferth D, Marmor RM, Hilbert PH. J. Org. Chem 1971;37:1379. (b) Gilbert JC, Weerasooriya U. J. Org. Chem 1979;44:4997. (c) Ohira S. Synth. Commun 1989;19:561. (d) Muller S, Liepold B, Roth GJ, Bestmann HJ. Synlett 1996:521.

16. The decision to use diastereomer cis-16b (as opposed to cis-16a) was rather arbitrary, determined by the available pure diastereomer at the time.

17. (a) Barluenga J, Aznar F, Liz R, Rodes R. J. Chem. Soc. Perkin Trans 1 1980:2732. (b) Barluenga J, Aznar F, Liz R. Synthesis 1984:304. (c) Barluenga J, Aznar F, Liz R, Cabal MP. Synthesis 1986:960.

Org Lett. Author manuscript; available in PMC 2008 September 10. 


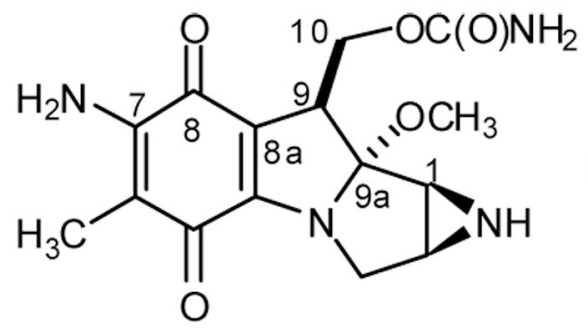

mitomycin C (1)

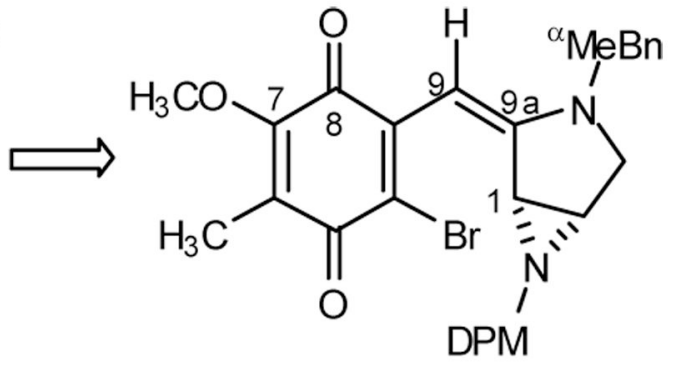

$4 a$<smiles>C=CC=C</smiles><smiles>C=C1[C@@H]2[C@H](CN1Br)N2O[Na]</smiles>

Figure 1.

Retrosynthesis of mitomycin C 


\section{glycine aldol, aziridine ring formation}

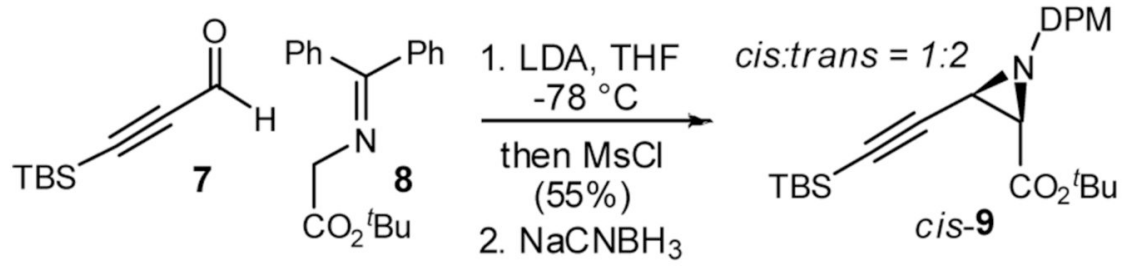

(65\% for cis-9, $89 \%$ for trans-9)

$$
\begin{gathered}
\text { •low overall yield } \\
\text {-low diastereoselection } \\
\text {-trans-selective }
\end{gathered}
$$

base-promoted aza-Darzens<smiles>CCCCCC(=O)OCC#CC=NO[Mg]</smiles><smiles>[Y20]O/N=C/C(=O)OCC</smiles><smiles>[M]ON=CC(=O)OCC</smiles>

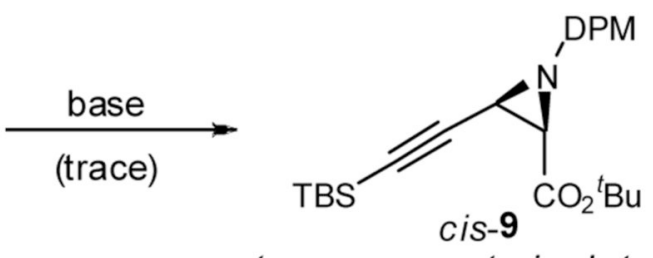

-trace amounts isolated

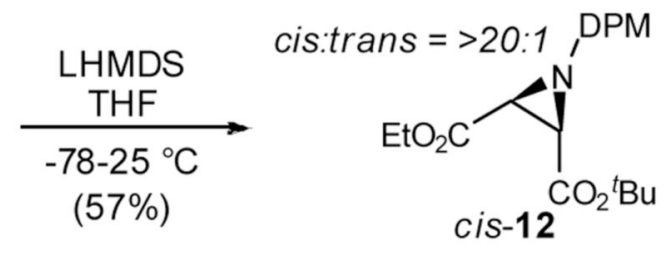

$$
\begin{gathered}
\cdot \text { moderate yield } \\
\text { - high diastereoselection } \\
\cdot \text { cis-selective }
\end{gathered}
$$
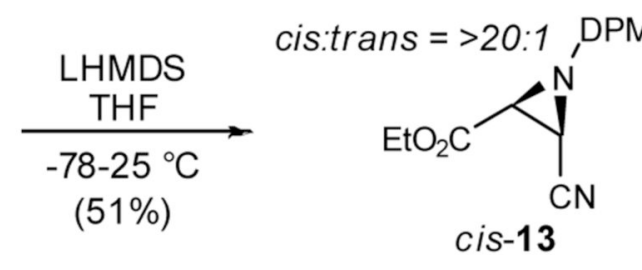

-low yield

-high diastereoselection

- cis-selective

Scheme 1.

Approaches to the synthesis of $c$ is-aziridine precursors to 6 


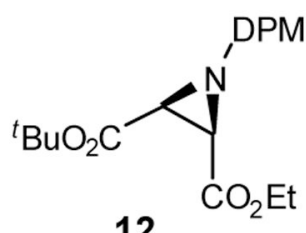

12

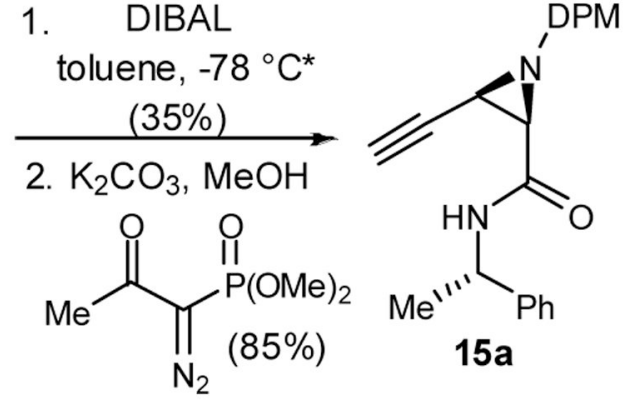

1. $\mathrm{NaOH}, \mathrm{EtOH}$

2. $(S)^{\alpha \mathrm{Me}} \mathrm{Bn}-\mathrm{NH}_{2}$ DCC, HOBT

(72\%)<smiles></smiles>

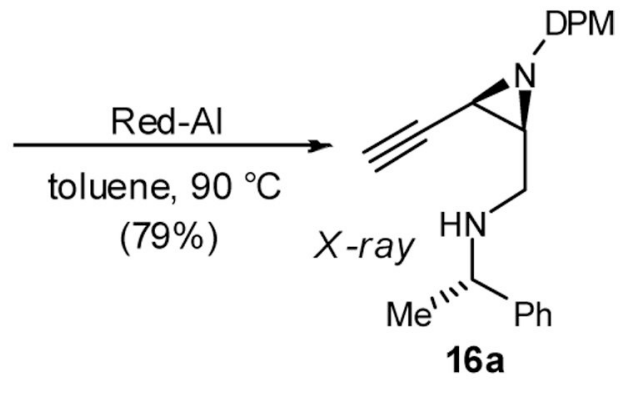

Scheme 2.

Synthesis of alkynyl amine $\mathbf{1 6}$

* then separate diastereomers 


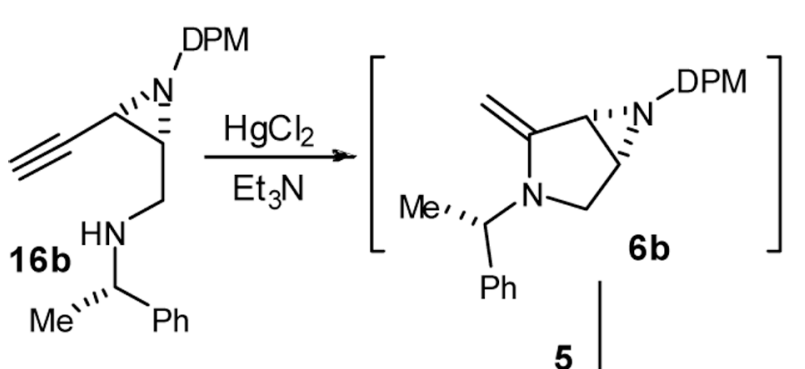<smiles></smiles>

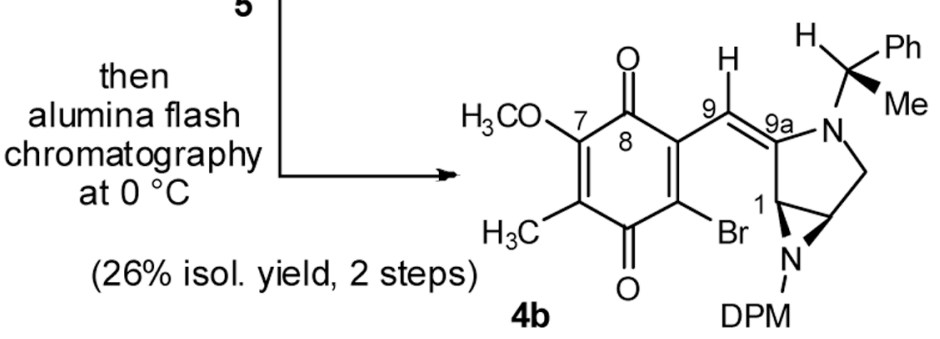

$t_{1 / 2} \approx 1.5$ days $\left(-15^{\circ} \mathrm{C}, d_{8^{-}}\right.$ tol)

Scheme 3.

Formation of the key enamine intermediate and subsequent alkylation to the mitomycin backbone 